\title{
Reflections of Socio-Cultural Changes on Urban Space in the 19th Century: The Case of Bursa
}

\author{
Elif Secer, Selen Durak, and Tulin Vural Arslan
}

\begin{abstract}
The Industrialization Movement in Europe since 18th century affected daily life in Ottoman Empire. Depending on military and political failures against Western countries, Ottoman Empire began to reorganize itself through making reforms by adopting the Western culture and civilization. Many innovations occured in the Ottoman Empire's economic, political and social order with the presentation of Tanzimat Edict in 1839. These Westernization efforts also affected the socio-cultural and spatial structure of Ottoman cities. Bursa, the first capital of Ottoman Empire, was among the significant examples where the reflections of these changes on urban fabric can be best observed. The aim of this study is to discuss the spatial transformation of Bursa from a typical Ottoman city into an industrial city. This discussion is based on the dynamics behind the emergence of new building typologies which differentiated from the traditional urban fabric with their functions and construction system.
\end{abstract}

Index Terms - Ottoman westernization, tanzimat reforms, urban transformation in 19th century, Bursa.

\section{INTRODUCTION}

In the 18th and 19th centuries fundamental changes occured all over the world, especially in Europe in the field of economy, society, military and architecture. The changes emerged after the Industrialization, affected Ottoman Empire as a neighbouring state of Europe. Economic and political decline in the 18th century entailed Ottoman Empire to make innovations in the State structure by adopting the Western culture and civilization. The political reforms that were practiced from the presentation of Reform Edicts in 1839 (Tanzimat) and in 1856 (Islahat) until the First Constitutional Era prevailed in 1876 affected the social life of the period and these changes had reflections on the urban structure throughout the Empire.

The first Ottoman capital Bursa is an ancient silk production and trade center. With the effect of Industrial Revolution, silk production became a significant industry for the city in the 19th century. During industrialization process, Ahmet Vefik Pasha was appointed in Bursa in order to implement Tanzimat reforms for the sake of modernization. Significant changes had been experienced in socio-cultural structure of the city in the 19th century with industrialization and Westernization efforts. Bursa is one of the cities where the reflections of the Modernization process and the distinctive changes in the traditional fabric of the Ottoman

Manuscript received December 31, 2014; revised May 4, 2015.

E. Secer is with the Interior Architecture and Enviromental Design Department, University of Bursa Orhangazi, 16310 Yıldırım, Bursa, Turkey (e-mail: elif.secer@bou.edu.tr).

S. Durak and T. V. Arslan are with the Architecture Department, Uludag University, Gorukle Campus, Bursa, Turkey (e-mail: selendurak@gmail.com, tulinv@yahoo.com). city in the 19th century can be best observed.

\section{InDUSTRIALISATION AND DEVELOPMENT OF THE Cities}

The urban structure of the cities all over the world, especially in Europe, had undergone prominent changes with Industrialization Revolution and the mechanization of production in the second half of $18^{\text {th }}$ century and especially in $19^{\text {th }}$ century. The increasing importance of trade and the access of technology in the city transformed production, transportation and communication systems. The decrease in the requirement for labour in agricultural economy and the surplus of the product caused migration from rural to urban areas and the population began to gather in the cities. The factories, which were the new layout of the form of production began to be located in the cities creating residential areas for the workers around. The increase in urban population and the developments in transportation systems necessitated the re-organisation of the cities. As a result, urban planning emerged as a new discipline in order to find solutions for the problems of industrial cities [1].

\section{A. Ottoman Empire in the $19^{\text {th }}$ Century}

The most prominent feature of the Ottoman Empire at the end of the 18th century was the loss of imperial land and the weakening of the central government [2]. Military failures led Ottoman empire to orient towards the West in order to gain strength. The initial Modernization movements began to flourish during the process called Ottoman Westernization Period. the presentation of Tanzimat Edict in 1839 was the concrete example of Westernization process indicating the changes in traditional structure of the Ottoman society.

The improvements in the sense of West was initially seen in military as a result of the failures against the West and land losses. During Tanzimat period, depending on the perception that European society was superior than Ottomans, amendments were made in the State's former organisation. Official institutions were reorganized according to the similar organisations in the West. In addition, improvements manifested itself in technology, science and education fields. Westernization affected the structure of the society leading to radical social changes [3].

The problems of social security, health and education institutions and social structure of the multi-national Ottoman society with diverse nationalities and religions can be seen as issues causing decadence. These issues were addressed by Tanzimat reforms, new regulations emerged in the State's order and the social structure [3]. Ottoman society, through making self-criticism, tried to improve its traditional structure in order to keep up with the West during the 19th century. 
As a result of the changes in the structure of the State and the society, new building typologies, that were not required until then, emerged in the Ottoman Empire. Military and official public institutions, health-care and industrial facilities, entertainment, commercial and accomodation buildings were embodied as the concrete samples of Westernization movements in cities during 19th century [4].

\section{B. From Traditional towards Industrial City: Bursa}

Bursa, after its conquest in 1326, became the capital of the State. Although in the following centuries when Edirne and Istanbul became the capital consecutively, Bursa didn't lose its importance. Ottoman rulers always attached great importance to Bursa that became a notable trade and production center due to its location and physical structure. Silk and spice exchange between East and West was realized through Bursa. Silk was also manufactured in the city. Until the 19th century, Bursa had an appearance of a typical traditional Ottoman city with its quarters developed around building complexes called kulliye [5].

The trade of silk which was manufactured in Bursa had an important place in the economy of the city. In the 18th century, fabrics manifactured more cheaper in Europe led to a decline in domestic weaving and an increase in demand for industrial production [5], [6]. In the $19^{\text {th }}$ century, growing demand for raw material in European countries, where industrial production had developed, steered Ottoman trade, especially the trade in Bursa.

The economic indicators changed in Bursa in the 19th century depending on the technological developments in the weaving sector. With Industrial Revolution in Europe, in steam-powered weaving industry, filature (spinning silk into threads) technology emerged. Ten years later, first filature factory was opened with the initiation of foreign investment in Bursa [7]. Sericulture, which was once manifactured with traditional methods, had undergone an industrial process in Bursa, leading the construction of factories that caused changes in urban structure [8].

19th century was Ottoman's orientation to West. However, the reason that initiated the change in Bursa was mainly the external factors [5]. Sericulture, which had an important place in city's trade, was the main cause of modernisation and affected the generation of new dynamics in the city.

\section{Urban Development during Westernization Period in Bursa}

Ottoman rulers sent officials to several cities in Anatolia and Rumelia who were expected to inspect the reforms made after Tanzimat and to improve central government. These inspectors were equipped with extraordinary powers who aimed at the realization of the reforms and the correction of deficiencies through observing local government [9].

Beatrice Saint Laurent specified that the State had identified Bursa as a pilot area for practising the reforms out of Istanbul [10]. In 1855, Bursa had experienced a majör earthquake which resulted in great damages. This situation might have influenced the selection of Bursa as a pilot area. Ahmed Vefik Paşa was appointed in Bursa in 1863 by the central government. He accomplished the first innovative movements in the city as an inspector in 1863 and 1864 and as a governor between 1879 and 1882 .

Before his task in Bursa, Ahmet Vefik Pasha witnessed the modernization process of Paris conducted by Baron Eugene Haussmann as a Paris Embassy. Through his guidance, the affects of Haussmann plan implemented in Paris could be observed in urban changes and development activities in Bursa [10].

In order to ensure the development of industrialization initiated by the foreign investors, Ahmet Vefik Pasha initially made improvements in transportation system. Peripheral roads were constructed in order to link Bursa with other major cities of Anatolia. The roads in the city were reorganized so as to ensure the communication between the city center and silk factories. Factories were linked to residential areas with new road connections which were planned in accordance with the modern means of transportation. Linear roads aimed at linking the historic city with the new buildings of Tanzimat period [10]. In order to ensure the transfer of raw material that were produced in factories overseas, a railroad line was opened linking Bursa with its port city Mudanya. In this way, raw material could be easily transferred to Marseille Port and then to Lyon, the silk production center of France [5].

Due to these developments, Ahmet Vefik Pasha initiated the first modern urban activities in the city. With the factories included in the skyline of the city and new transportation routes, Bursa began to transform into an industrial city [11].

\section{REFLECTIONS OF SOCIO-CULTURAL CHANGES ON URBAN SPACE IN THE $19^{\mathrm{TH}}$ CENTURY}

The change of manifacturing in raw silk industry from domestic production to mechanization began to transform the city's social fabric. Industrialization movement impacted both physical and social structure in Bursa. In the early 19th century, following the establishment of silk factories in Bursa, sericulture became an important field of activity, especially among non-Muslims. Therefore silk factories, which had to be located near water resources, had chosen regions especially where non-Muslims inhabited [11]. There were eleven silk factories in the 19th century urban fabric in Muradiye, Demirkapi, Mecnundede, Umurbey ve Karaagac Quarters (see Fig. 1) [8].

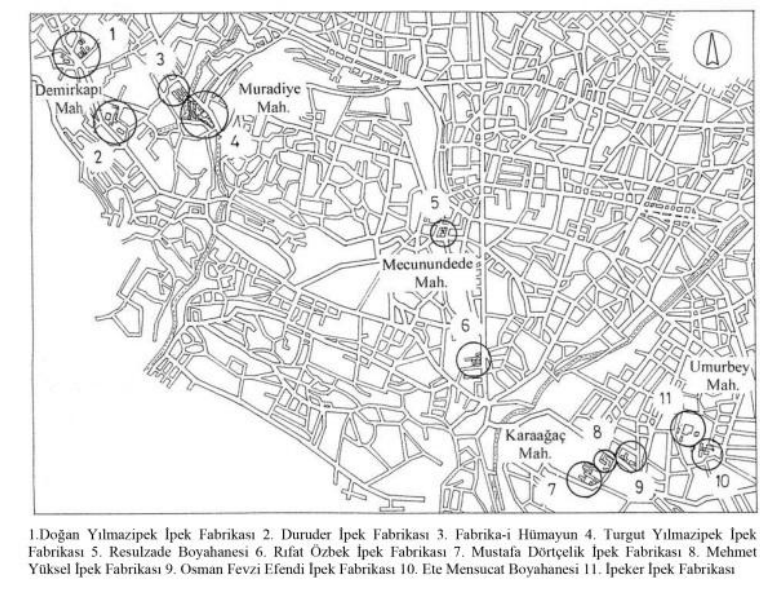

Fig. 1. Location of silk factories in Bursa in the $19^{\text {th }}$ century [8].

Factories, although a new building typology in the 19th century, are not included in this study in terms of their 
architectural characteristics. This study focuses on the impact of socio-cultural changes after the factories were introduced in the urban fabric.

Big fires that demolished a large urban area in 1800s and the earthquake that occured in 1855 causing great damages in the city, necessitated urban development and construction of new buildings.

Following the 1855 earthquake, the first plan of the city was drawn in 1858 by Suphi Bey, who was a surveyor in a military school. This plan guided the reconstruction of the city. With Modernization project, the physical fabric of the city was no longer organic, urban areas were planned in line with certain geometrical principles [12].

During this period, the physical fabric of the traditional Ottoman urban neighbourhood had changed. Socio-economic differences began to be considered in residential areas. Traditional Ottoman city consisted of quarters with narrow, dead-end streets structured in accordance with the topography spontaneously. In order to update the physical structure of the city for contemporary means of transportation Ahmet Vefik Pasha made radical changes in the urban fabric. He opened big avenues through removing dead-end streets and demolishing some buildings that were located on that routes [10]. In this period, grid-iron plan began to shape the physical structure of quarters where organic urban structure existed until the mid-19th century [5].

In this period, the necessity of reconstruction in old quarters which were demolished by big fires emerged in Bursa. For example, an Armenian quarter in Setbasi was demolished by 1863 fire damaging the urban pattern. Ahmet Vefik Pasha provided a new plan for this region in which the streets intersected vertically forming a grid [12]. With this plan, a new avenue called İpekcilik Street (named after sericulture) was opened and the region began to be inhabited by rich silk merchants. There was not a differentiation in terms of ethnicity and religion; the residences of Muslims, non-Muslims and foreigners lined up together. The quarters along the street became the location of upper-level income groups [10].

Ottoman rulers prevented the use of timber as a construction material in the new buildings in order to avoid the spread of fire, and encouraged the construction of masonry buildings. It could be observed that the use of timber was reduced after 1863 fire [13]. Bursa began to acquire a modern appearance rather than a traditional Ottoman city thereafter.

In the $19^{\text {th }}$ century, within the context of Modernization project that was initiated with Tanzimat Edict, new construction techniques and building typologies, that were not existing in Ottoman cities before, began to emerge in Bursa. The new building typologies can be listed as administrative buildings, banks opened as a result of the new financial system, railway stations and ports that emerged due to the innovations in the transportation system, institutions established depending on the arrangements in the field of education and health.

During the Modernization process of Bursa, in addition to the Tanzimat ideology of Ottoman Empire, industrialization in silk manifacture played an important role in the transformation of the traditional structure in socio-cultural sense. The presence of the foreign investment in silk trade in
Bursa affected the urban population and culture in the $19^{\text {th }}$ century. After the Industrial Revolution, with the change in daily life, buildings for entertainment and tourism emerged as new social spaces generated by the Western culture of foreign and non-Muslim inhabitants.

\section{A. The Change in Administrative Structure}

The reforms that were put into practise after the Tanzimat Edict included administrative, political, social and economic regulations in Western sense. Public buildings for administrative affairs didn't exist in the urban fabric until the 19th century. Government palace and town hall were the buildings developed as a result of the new administration approach. Government palaces were the symbols of central government in provinces, aimed at reinforcing the central government through making local legislations [14].

\section{1) Government palace}

Innovation practices that were applied in the context of city administration regulations were public squares in front of the government palace. The most important element in the square was the government palace which included several departments such city court, police, public works, trade and agriculture, education, foreign affairs, and revenue offices. In addition to this, prisons were located in relation with the government palace. Western building forms, that were reflecting the ideology of the period, were dominant in the overall structure of buildings [14].

The first reflection of Tanzimat reforms in the center of the city was the Government Palace that was constructed in 1863. The building, surrounded by walls, generated a focus in the city center. Town hall, theatre and post-office were also located in this region which were constructed during the governorship of Ahmet Vefik Pasha, [12]. It is claimed that government palace, post-office and prison were displayed together on the city maps [15].

The goverment palace and the theatre were reflecting European architecture in terms of plan and form (Fig. 2). Town hall and post-office were reflecting traditional Ottoman fabric in terms of construction methods and material. Saint Laurent determined the location of government palace as the public square on which the statue of Ataturk is located now. Three-storey masonry building was constructed with brick, stone and stucco and had a rectangular plan. It had a simple facade with minimal ornamentation. There were the rooms for the judge on the ground and first floors and governorship on the second floor [15].

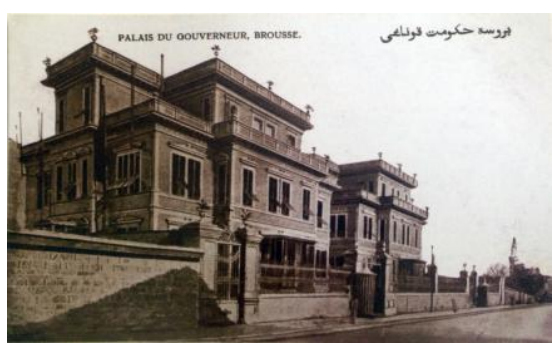

Fig. 2. Government palace [16].

Edmund Dutemple, who worked as a French consul in Bursa in 1880, claimed that the government building was constructed in neo-classical style and emphasized the similarity with other administration buildings all over the 
Ottoman Empire in this period. In addition, he resembled this building to an Ottoman residence, since the ground level rooms were located around a close courtyard [15].

\section{2) Town hall}

After the first municipality established in Istanbul in 1854, in 1866, it was determined that all municipal works should be disseminated all over Anatolia. In Bursa a municipality was organized in 1867 in order to realize modern urban activities. [13]. Town hall was located in the vicinity of government palace. (See Fig. 3) Post-office and theatre were also located in that same region [12].

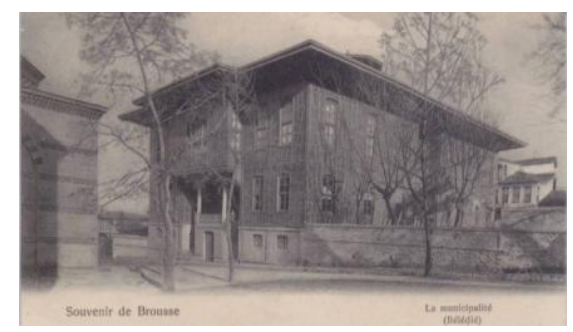

Fig. 3. Town hall [16].

\section{B. New Financial Relations and Services}

\section{1) Ottoman bank}

The necessity of a financial insitution emerged depending on industrialization, the establishment of factories, and new financial relations. Ottoman Bank, which was founded in Galata, Istanbul in 1856, opened its first branch in 1875 in Silk Khan, located inside Bursa Historical Bazaar and Khans Region. This condition displayed the impact of new financial relations on site selection of the financial institution [12]. The branch changed its location 20 years later (see Fig. 4) [7].

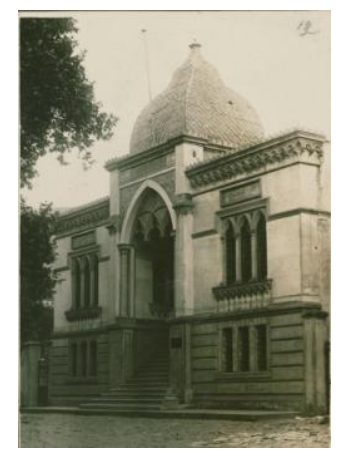

Fig. 4. Ottoman bank [17].

\section{2) Consulate buildings}

In order to protect the financial interests of foreign states, and preserve the rights of foreign citizens and tradesmen, Ottoman Empire gave some foreign states the right of being represented. These states initiated consulate facilities in Istanbul, then in Bursa in line with the increased commercial relations [7]. According to the provincial annuals published in 1870 , it was claimed that the countries which appointed consuls in Bursa were Greece, Italy, France, Russia, Germany, and Austria-Hungary. Consulates located in quarters inhabited by non-Muslims. For example, French Consulate located inside Armenian Quarter (see Fig. 5), Germen Consulate located inside Jewish and Greek quarters [16]. Consulates were also concerned with the activities of
non-Muslim education institutions [7].

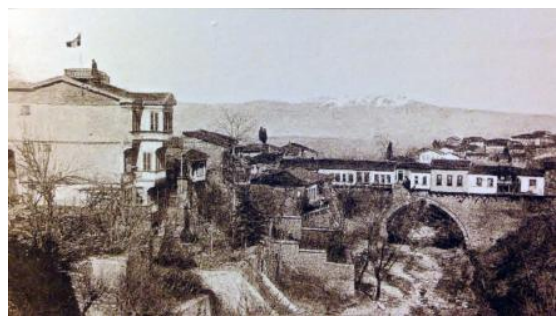

Fig. 5. French consulate [16].

\section{Landmarks: Clock Tower}

Clock towers, which began to be built in the 19th century in line with Tanzimat reforms, were standing as landmarks indicating the power of the State [18]. Clock towers show the flow of time and change time-space perception [19].

The first clock tower in Bursa was built in 1900, but demolished soon after. In 1905, a new clock tower was built and opened on the day when Abdülhamit II. became the new ruler (see Fig. 6) [13].

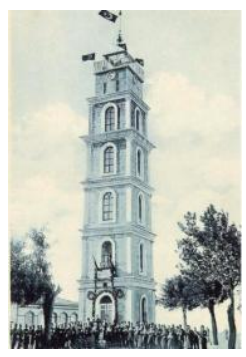

Fig. 6. Clock tower [16].

\section{The Change of Daily Life: Theatres, Hotels, Cafes, Restaurants and Casinos}

In the 19th century, with industrialization, increasing number of foreign investors and non-Muslims began to affect city population and culture. With the new routes opened in the context of modernization initiated by Ahmet Vefik Pasha, the reinforcement of communication of the city with other cities, and the development of transport by sea increased the number of foreign travellers and tourists [20]. There had been a change in the socio-cultural structure of the city depending on the increase in population whose culture differed from traditional Ottoman society and who were granted rights in the context of Tanzimat reforms. The needs and expectations of a different culture led to the generation of new buildings for entertainment, which hadn't seen in the urban fabric before. A theatre, cafés, restaurants, casionos and hotels began to take place in the $19^{\text {th }}$ century Bursa.

\section{1) A western art: Theatre}

Theatre, which was the significant indicator of Westernization, began to spread among Ottoman society as a new entertainment mean [4]. Ahmet Vefik Pasha was known for his interest in theater and the translations he made from Moliere's plays. He provided the construction of a theatre building in Bursa and organized plays with the performers he invited from Istanbul [10].

The theater building was constructed in 1879 in the city center, where today a financial institution is located. The 
building was demolished by fire during the First World War. It was claimed that the building was in neo-classical type and was constructed with stone and timber. Its facade had a pediment. In the garden in front of the theatre, there was a pond (Fig. 7). The building on the opposite of the theatre was claimed to be the Government Palace [15].

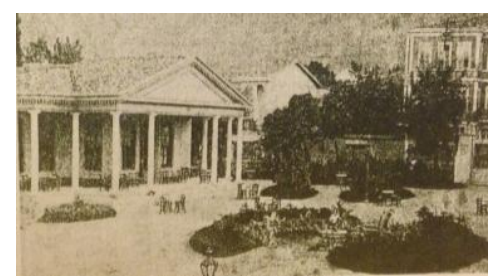

Fig. 7. Theatre [15].

\section{2) Tourism buildings: Hotels}

Bursa, as an ancient Ottoman capital, was a city of considerable interest for local and foreign tourists with its historic and natural resources. During industrialization period in the 19th century, sea transport began through Gemlik and Mudanya Ports of Bursa and inner-city transport routes were improved. In this period, Cekirge Road, which was linking city center with the thermal baths, had been expanded. The number of visitors increased depending on these improvements in the 19th century. As a result, in order to meet the need for accomodation, new building typologies emerged [20].

In Anatolia, since Seljuk Period, khans and caravanserais provided accomodation services to travellers and passengers besides being commercial centers. However, with the change in socio-economic conditions and the perception of comfort in the 19th century, these buildings couldn't provide the expected physical conditions anymore [20]. A new building typology, hotels emerged in the Modernization Era.

The first hotel in Bursa was opened by foreigners engaged in trade in 1850s. Hotel D'Anatolie, opened by Madame Brotte (Fig. 8), was one of the hotels providing service in those years [12].

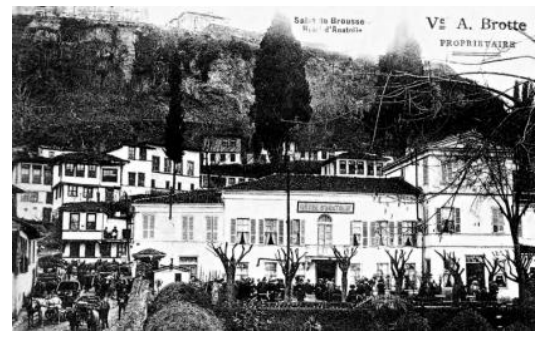

Fig. 8. Hotel d'anatolie [19].

In 1869 , foreigners was ensured the right to property with legislations which encouraged them to make investments. The hotels, opened in Bursa after these developments, were one of those investments. Hotels were located especially in Cekirge region where there were many thermal baths [13], and also in Setbasi region where Armenian and French population were dense. The customers of these hotels were the tradesmen, travellers and foreign visitors who came for the Consulates [20].

3) Cafes, restaurants and casinos

In traditional Ottoman society, there were coffee houses where only men could attend and public promenades where women and men could go together for entairtainment and recreation. In the 19th century, with the changing profile of the urban-dwellers and increase in non-Muslim population, places for entertainment, in Western sense, began to be opened in Bursa.

The first cafes were opened in Cekirge and Altiparmak where thermal baths and hotels were densely located and in Setbasi where non-Muslim population was dense. Restaurants were another new typology which provide service for especially foreign visitors. Casinos, where musical activities took place, began to be opened in tis period. There were generally restaurants and casinos within the hotels [20].

\section{E. Health Institutions}

After the 1855 earthquake that caused great damage, the first Ottoman hospital, which was opened in 1390s, couldn't provide service properly due to the incresing amount of patients and injured people. Ahmet Vefik Pasha, when appointed to Bursa, aimed to establish a modern hospital in order to solve the health service problem. He selected the first settlement place in Bursa for the location of the hospital (Fig. 9). This region is known as Hisar (named after the citadel) located on a high topography, dominating the town.

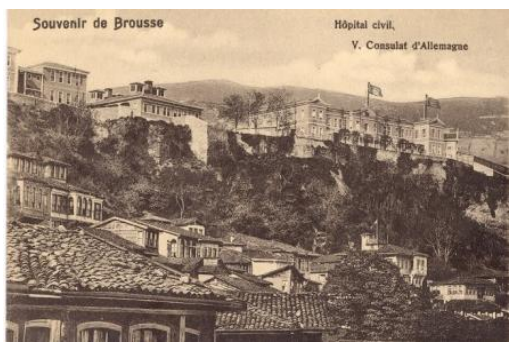

Fig. 9. Gureba hospital [16].

Ahmet Vefik Pasha expropriated an existing house in Hisar and opened the hospital with the name Gureba (for people in need) in 1868. In 1879, a two-storey hospital with masonry construction was built. In the following years, new buildings were added to this building. However, the first building initiated by Ahmet Vefik Pasha was destroyed by a fire in 1956. This hospital have survived until now as being modernized [21].

\section{F. Educational Institutions}

Another important field of Modernization movement was the establishment of educational institutions opened on several fields in order to meet the need for trained people who would be the practitioners of the reforms carried out by the State. The religious educational institutions called madrasas, which were the core of education system until the 19th century had not been improved during this period. Rather new institutions giving education in Western sense were being established.

The reforms in the education field in Bursa gained acceleration after the creation of institution that would carry out the duty of Directorate of Education in 1879. During this period, with the establishment of new institutions providing modern education, non-Muslims and foreigners living in Bursa opened several schools with the rights they attained. 


\section{1) Military school}

The improvements initiated in the Ottoman Empire began in the military system first, depending on military failures and land losses. With the changes in the army organisation, a new military education approach was required. In 1845, a military school was established in Bursa with this aim [13]. The first school building was built in the center of the city opposite the theatre. In 1892, the school moved to a two-storey masonry building (Fig. 10), that was reflecting the common architectural approach of the period.

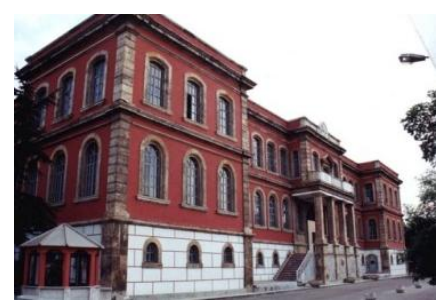

Fig. 10. Military school [22].

\section{2) The school of industry}

In Ottoman Empire, there were reformatories opened for training orphans who would be beneficial to society in future. During Tanzimat Period, reformatories were transformed into vocational schools. The first reformatory in Bursa was opened in 1869. In 1889, it moved to Hisar region, and began to provide vocational training [23].

\section{3) The school for civil services}

Changing political and social order with the implementation of Tanzimat reforms, emerging new institutions such as town hall, post office and financial institutions which didn't exist in the urban fabric before, led to the requirement for education of administrative staff.

In order to meet the need for officers required by the Ottoman Bureaucracy, in 1883, the School of Civil Service was opened in a house first. Then, it moved to a two-storey masonry building with a balcony standing on columns on the front facade in 1885 (Fig. 11) [13].

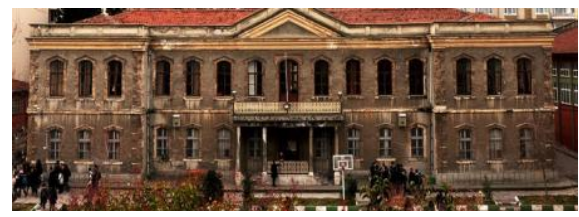

Fig. 11. The school for civil services [24].

\section{4) The schools for teachers' training}

Within the context of Tanzimat Reforms, teachers' training became an important field of improvement. Therefore, schools of teachers began to be established. In Bursa, a school training boys, who would be employed in institutions giving education with modern methods, was opened on Ipekcilik Street, in 1884 (Fig. 12).

With Modernization, the traditional structure of Ottoman society began to be changed. The education of girls began to be considered and new institutions were opened with this aim In 1901, a teachers' school training girls was opened in Bursa [13]. It was a two-storey masonry building with a balcony standing on columns and arched windows on the front facade (Fig. 13). The ornamentation above the balcony was reflecting the aesthetic approach of the period [16].

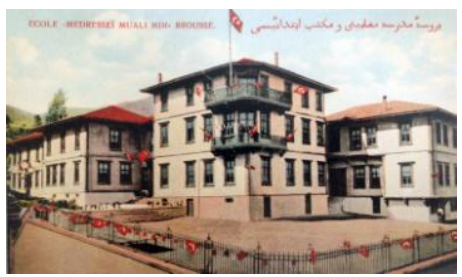

Fig. 12. Teachers' school for boys [16].

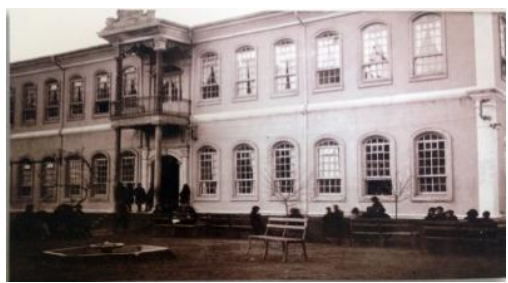

Fig. 13. Teachers' school for girls [16].

\section{5) The school of agriculture}

In history, agricultural activities had been an important source of income in Bursa. During Industrialization, in Bursa, The School of Agriculture was established in order to develop modern cultivation methods and improve productivity. The school was located on a vast land in Hurriyet region far from the city center (Fig. 14.) [13].

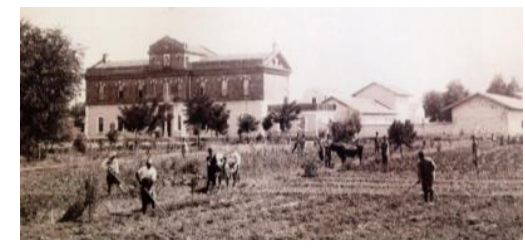

Fig. 14. The school of agriculture [16].

\section{6) The schools opened by foreigners}

Education was one of the fields that foreigners made investments with the rights they attained in Ottoman Empire. Among the schools that foreigners established in Bursa was The School of Sericulture opened by French capital in 1888. The aim of the school was to provide training in sericulture and support the local silkworm production. In 1894, it moved to a building reflecting aesthetic approach of Westernization period (Fig. 15). This school was located in Setbasi district where Armenian and French population were dense. The architecture of the school was similar with French schools and residences at that time depending on the relations started with France on raw silk trade [5].

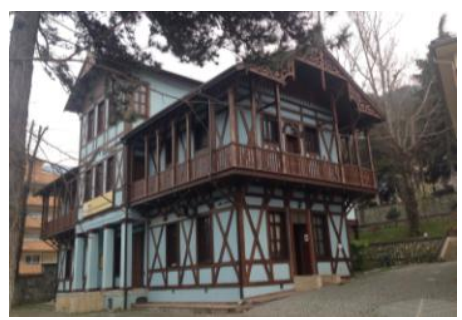

Fig. 15. The school of sericulture [elif secer archive].

In 1820, with the support of 'American Board of Commissioners for Foreign Missions' American schools 
began to be established in Ottoman Empire. The first American School was opened in Bursa in 1867 [13]. The school was located in Muradiye where the Greek population was dense.

There were also four schools opened by French commission of missionaries at the end of the 19th century in Bursa [25]. There was also a particular focus on site selection of new schools. Vocational school was located in Hisar, agriculture school was located in Hurriyet far from the city center. Foreigners' schools were established inside their community districts. Mainly the educational institutions, such as the school of sericulture, the schools for teachers' training and the school for civil services were located on the south of Ipekcilik Street.

\section{CONCLUSION}

Industrialization Era, that began in the late 18th and 19th century in Europe, affected Bursa which had commercial relations with European countries on raw silk trade. During this period, Bursa had become an Ottoman city experiencing social changes similar to cities being industrialized. The growing impact of Modernization Movement in Ottoman Empire since the 18th century, began to influence the socio-cultural structure with new legal arrangements. These changes were manifested by new urban planning approach and new building typologies that were not existing in the city before.

Buildings that were constructed in that period with the 19th century techniques, rather than traditional methods, were in a sense, symbolic structures manifesting the changing modern face of the State. The change in the 19th century Ottoman society initiated urban developments in Bursa which had a traditional character before. The city is a significant example where the impact of Ottoman Westernization trials on the public space can be best observed. The social and spatial transformation that Bursa experienced in the 19th century, can be accepted as the reflection of socio-economic change of Western countries after Industrial Revolution in Ottoman Empire.

\section{REFERENCES}

[1] S. Durak, "Railways in Anatolia as a modernization project and Bursa-Mudanya railway line," M.S. thesis, Dept. Architecture, Uludag University, Bursa, Turkey, 2003.

[2] M. Ş. Hanioğlu, A Brief History of the Late Ottoman Empire, Princeton University Press, New Jersey, UK, 2010.

[3] Z. Çelik, The Remarking of Istanbul, Portrait of an Ottoman City in the 19 Century, part II, University of California Press berkely and Los Angeles, California,1993.

[4] A. Ertugrul, "Different types of structure in the Ottoman Empire in the $19^{\text {th }}$ century," Journal of Turkey Research Literature, vol. 7, no. 13, pp. 293-312, 2009.

[5] N. Dostoğlu, "Urban development of Bursa in the modernization era," in Proc. Ottoman Modernization and Bursa Symposium, C. Çiftçi, Ed., Osmangazi Municipality, Bursa, Turkey, 2009.

[6] F. D. Karakoç, "Social and cultural life of Bursa before $20^{\text {th }}$ century," in Proc. Ottoman Modernization and Bursa Symposium, Osmangazi Municipality, Bursa, Turkey, 2009.

[7] Z. D. Abac1, "Foreign consulates in Bursa (19 th $^{\text {th }}$ century)," in Proc. Ottoman Modernization and Bursa Symposium, C. Çiftçi, Ed., Osmangazi Municipality, Bursa, Turkey, 2009.

[8] E. Ö. Oral and Z. Ahunbay, "The conservation of the heritage of Bursa sericulture industry," Journal of ITU/a Architecture, Planning, Design, vol. 4, no. 2, pp. 37-46, 2005.
[9] M. Öntuğ, Anatolia Right Arm Inspection of Ahmed Vefik Pasha, Palet Publishing, İstanbul, pp. 9-11, 2009.

[10] Y. Dinçer, "Reformer fed by tradition: Vefik pasha," Bursa through the Window of Literature, Osmangazi Municipality, Bursa, pp. 67-78, 2007.

[11] S. Kaygalak, "Rural, urban and transition to capitalism: The case of Bursa," Mülkiye Journal, vol. 31, no. 257, pp. 186-203, 2007.

[12] İ. Tekeli, "Three different transition period on history of bursa," Systems and Dates of Settlement in Anatolia, Tarih Vakfi Yurt Publishing, İstanbul, pp. 332-368, 2011.

[13] N. Kumaş, "The social life in Bursa in the period of Abdulhamid II (1876-1909)," Ph.D thesis, Dept. History, Uludag University, Bursa, Turkey, 2011.

[14] İ. Ortayl1, "Interview: Ottoman government today mansions," Journal of Architecture, no. 203, pp. 3-6, 1984.

[15] S. Polat, "Proposed a method for evaluating architectural identity in public outdoor spaces: Case of Bursa-Republican field," Nilüfer Municipality, Bursa, Turkey, 2013.

[16] N. Dostoğlu, Bursa in the Ottoman Period, MCRI Press, Turkey, 2002.

[17] Ottoman Bank. [Online]. Available: https://www.archives.saltresearch.org

[18] Ö. Aydın, "Representing symbols of the emperor/empire in the buildings of sultan II abdulhamid period," Journal of Architecture, Ankara, no. 364, 2012

[19] B. Güvenç, "Architecture: Time, space and change," in Time-Space, S. Ural, Ed., YEM Publishing, İstanbul, Turkey, 2008, pp. 109-117.

[20] İ. Yaşayanlar, Hotels of Bursa in Ottoman Period, Nilüfer Municipality, Bursa, Turkey, 2013.

[21] C. İrgil, "Bursa health history (historical development of health services in bursa)," Bursa Defteri, Bursa, Turkey, pp. 96-98, March 2003.

[22] Military School. [Online]. Available: https://www.panaromia.com

[23] M. A. Y1ldırım, "Overview of the development of vocational- technical education in the ottoman province: Bursa industrial school," Journal of Blacksea Research, no. 37, pp. 71-90, Spring, 2011.

[24] The School for Civil Services. [Online]. Available: http://www.bursaerkeklisesi.k12.tr

[25] İ. Yaşayanlar, "Activities of mission les soeurs de charité in Bursa," Bursa'da Yaşam, Bursa, pp. 82-85, 2014.

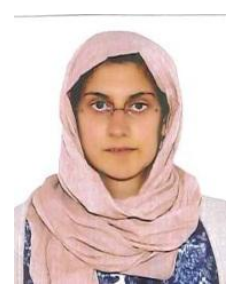

Elif Secer was born in Izmir in 1988. She started architecture education in Anadolu University, studied in Universidad de Alicante and Yildiz Technical University from 2010 to 2011 and graduated as an architect from Anadolu University in 2012. She started to master degree in Uludag University, Faculty of Architecture in 2013 and continues there.

She worked documentation and conversation and works as an architect with in historical sites and buildings in Turkey. Now, she is working as a research assistant in Bursa Orhangazi University Faculty of Architecture. Her field of interest is sense of place, history of architecture, Ottoman architecture and culture.

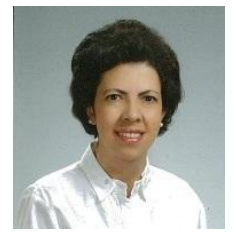

Selen Durak was born in Bursa in 1974. She completed her bachelor degree of architecture in Middle East Technical University in 1996, and finished her master degree of architecture in Uludağ University Architecture Department in 2003 and PhD degree in Middle East Technical University, Faculty of Architecture in 2010.

She has been an architect for eighteen years in Turkey. Now she is working as an associate professor in Uludağ University Faculty of Architecture. Her field of interest is universal and inclusive design, children's environments, history of architecture and cultural heritage.

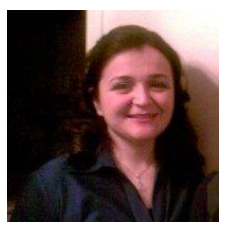

Tulin Vural Arslan was born in Bursa in 1974. She completed her bachelor degree of architecture in Middle East Technical University in 1996, and finished master degree in Middle East Technical University, Faculty of Architecture in 1999 and $\mathrm{PhD}$ degree in Istanbul Technical University, Faculty of Architecture in 2005.

She has been an architect for eighteen years in Turkey. Now she is working as an associate professor in Uludağ University Faculty of Architecture. Her field of interest is architectural design, design of shopping centers and the development and transformation of commercial districts in historic city centers. 